\title{
An Investigation of Students' Perceptions about Democratic School Climate and Sense of Community in School ${ }^{\mathrm{i}}$
}

\author{
Memet Karakuş \\ Faculty of Education, Çukurova University, Turkey
}

Copyright $(2017$ by authors, all rights reserved. Authors agree that this article remains permanently open access under the terms of the Creative Commons Attribution License 4.0 International License

\begin{abstract}
This study aims to investigate students' perceptions about democratic school climate and sense of community in school. In line with this purpose, it aims to find answers to the following questions: How democratic do students find the school climate? What is students' sense of belonging level at school? What is the academic success level of students? Is there a significant relationship between students' democratic school climate scores and sense of community in school scores? The study, which was designed as a descriptive one to identify the present situation, made use of democratic school climate scale as data collection tool. Students' academic success was evaluated based on their grade point averages. The participants were students in a School of Foreign Languages department in a university in southern Turkey. The study utilized descriptive statistics and Pearson product-moment correlation coefficient analysis techniques. It was found that students' sense of community in school perceptions were higher than their perceptions about democratic school climate. Although there was not a high relationship between academic success and perceptions about sense of community in school and democratic school climate, students with very low academic success had low perceptions about democratic school climate and sense of community in school. As for those with very high academic success, they were found to have high perceptions in relation to these variables. In line with the findings obtained from the study, some recommendations were made for democratic school climate.
\end{abstract}

Keywords Democratic Education, School Climate, Sense of Community in School

\section{Introduction}

Democracy is a concept related to many values such as the way of life, culture and management style. It also includes 1 . love, respect, equality, participation, reconciliation, refraining from violence, human worth, liberty, tolerance, freedom of thought and expression, political pluralism, rule of law, different ideas of community and solidarity, but democracy in general sense means individuals' expressing their ideas freely. Education has an important role in terms of understanding and living democracy. In order for education to fulfill this important role, the school climate should be democratic. Therefore, students' perceptions about how democratic the school climate is and sense of community in school is a topic worth investigating.

School climate refers to the quality and character of school life. Educators have written about and studied school climate for years. School climate is based on patterns of people's experiences of school life and reflects norms, goals, values, interpersonal relationships, teaching and learning practices, and organizational structures [1].

In Turkey and in all over the world democracy, democratic education and democratic values have become extremely important issues. Education has an important role in teaching, living and improving democracy, so it is important to create a democratic environment in schools.

A multitude of factors color significant group trends that in turn shape the quality and character of the school or school climate [2]. Educators' perceptions about education and their practices towards students are determining factors for giving a democratic education.

As the curriculum is prepared by educators, it is inevitable to be teachers' monopoly no matter how democratically it is prepared. Many non-democratic practices at various levels of education are remarkable, such as threatening with grades, committing violence, not respecting to diversities, not being fair and equal.

This study aims to investigate students' perceptions about democratic school climate and sense of community in the schools. In line with this purpose, the main questions addressed in this paper are as follows:

How democratic do students find the school climate? 
2. What is the students' sense of community level in the school?

3. What is the students' academic success level?

4. Is there a significant relationship between students' democratic school climate scores and sense of community in the school scores?

\section{Method}

The study, which was designed as a descriptive one to identify the present situation, made use of democratic school climate scale as data collection tool. The Democratic School Climate Scale is developed by Flanagan. Eight items focus on the establishment of democratic processes within the school system. Responses were rated on a 5-point scale and reverse-scored such that $1=$ strongly disagree and $5=$ strongly agree. Alpha reliability for the five-item scale was .75 and all the items loaded on one factor in a principal components analysis. Items were averaged for the measure of individual perception of democratic school climate. Besides this, students' sense of community level in the school and how democratic they find the school climate were assessed by their own opinions. They were given a point between 1 to 5 for their sense of community in the school. Students' academic success was evaluated based on their grade point averages. The study utilized descriptive statistics and Pearson product-moment correlation coefficient analysis techniques. The participants were 114 third-grade students in a School of Foreign Languages department in a university in southern Turkey.

\section{Findings}

Findings obtained from the study are given below respectively in parallel with the questions being asked in the survey.

\subsection{Students' Perceptions about Democratic School Climate}

Below is the list of items and the mean scores of students' perception.

As seen in the Table 1, except for the first item, all the other items' averages are 3 and above 3 . This situation can be interpreted as students do not have too much say in how the school is run. Seven items on the scale are related with teachers and 1 is about students. The only item about students has the lowest average and this is noteworthy.
Table1. Students' perceptions about democratic school climate

\begin{tabular}{|l|c|}
\hline \multicolumn{1}{|c|}{ Item } & Mean score \\
\hline 1. Students have a say in how the school is run. & 2.11 \\
\hline 2. Teachers listen to students' ideas. & 3.19 \\
\hline 3. Teachers expect students to respect one another. & 4.09 \\
\hline 4. Teachers give all students a fair chance. & 3.22 \\
\hline $\begin{array}{l}\text { 5. Teachers treat students as individuals, not as } \\
\text { members of groups. }\end{array}$ & 3.29 \\
\hline $\begin{array}{l}\text { 6. Teachers won't let students make fun of other } \\
\text { students. }\end{array}$ & 3.57 \\
\hline $\begin{array}{l}\text { 7. Teachers expect students to listen to each other's } \\
\text { opinions. }\end{array}$ & 3.88 \\
\hline $\begin{array}{l}\text { 8. Teachers put a stop to students threatening other } \\
\text { students. }\end{array}$ & 3.54 \\
\hline
\end{tabular}

\subsection{Students' Perceptions about Sense of Community Level in the School}

The table, which is below, shows students' perceptions about sense of community level in the school with their frequency and percent.

Table 2. Students' sense of community level in the school

\begin{tabular}{|c|c|c|}
\hline Level & Frequency & Percent \\
\hline Very high & 14 & 12 \\
\hline High & 32 & 28 \\
\hline Medium & 32 & 28 \\
\hline Low & 20 & 18 \\
\hline Very low & 16 & 14 \\
\hline Total & 114 & 100 \\
\hline
\end{tabular}

According to the Table 2, there are $36(32 \%)$ students with low and very low, and also there are $46(40 \%)$ students with high and very high level sense of community in the school. $32(28 \%)$ students have medium sense of community level. Even though the percentage of the students who have high sense of community level is more, it is remarkable that $32 \%$ of the students have low sense of community.

In order to have more information, students are asked to write a slogan and draw a picture to express their feelings. The findings in this regard are given below:

\subsection{Slogans and Pictures Expressing Students' Feelings about the School}

In this survey, students are asked to express their feelings about their school with a slogan and picture. Some of the slogans in this respect are given as follows:

6. Schools kill creativity

7. A place in which unnecessary things which will never work in real life are taught.

8. Frustration

9. Studying is pretty well but not schools.

10. Many green areas but no peace

11. I wish it would end and we could go.

12. Damn walking egos! 
When the slogans of the students are examined, it is seen that there are slogans expressing both positive and negative feelings of students about their school. However, it is remarkable that there are many slogans expressing negative feelings. On the slogans 1,2 and 3, it is seen that the students emphasize their love towards the school and the unifying dimension of the school. On the slogan 4, even though it emphasizes the school's role of development of intelligence at first sight, it may attempt to explain indirectly that the school is an information- uploading system. On the 5th one, it can be said that the students are trying to explain their grade anxiety in a humorous way. The 6th slogan and the following slogans seem quite pessimistic and negative. On the 6th, 7th and 8th slogans, students may try to express that school kills creativity and it is an institution where things that would not work in real life are taught, and they also may try to express their frustration on this point. On the 9 th, there is a negative reaction not to study but to schools is observed. Although natural beauty of the school is emphasized, there is also the emphasis of uneasiness on the 10th slogan. On the 11 th, there is boredom towards the school and a desire to finish it as soon as possible. On the last one, it can be said that the students are emphasizing the difficulty in communicating with the instructors.

Some of the pictures that express the students' feelings about the school are given below:



Figure 1. Pictures of the students' perception of the school environment

When the pictures of the students' perception of the school environment are examined, it can be said that there is negative feelings about the school in general. Music, entertainment and happiness are observed in picture A. This case can be interpreted as the student feels happy at school. On the Picture B, a person standing on the edge of the cliff and thinking about the future is seen, so it can be said that there is an emphasis on uncertainty of the future. In the Picture $\mathrm{C}$, a crushed student under the books is given. Here, the difficulty of the lessons may be emphasized. In the picture D, a student is depicted behind iron bars. In this picture, the boringness and monotony of the school may have been tried to be depicted. In the Picture E, a student who is unhappy and walking with a mask is seen. The student may try to depict that she cannot be herself and she is upset because of this.

\section{Students' Academic Success Level}

The frequency and percent of students' academic success levels are given below:

Table 3. The frequency and percent of students' academic success level

\begin{tabular}{|c|c|c|c|}
\hline Range & Level & Frequency & Percent \\
\hline $3.5-4$ & Very high & 20 & 20 \\
\hline $2.9-3.4$ & High & 41 & 40 \\
\hline $2.3-2.8$ & Medium & 28 & 27 \\
\hline $1.7-2.2$ & Low & 10 & 10 \\
\hline $1.1-1.6$ & Very low & 3 & 3 \\
\hline \multicolumn{2}{|c|}{ Total } & 102 & 100 \\
\hline
\end{tabular}

As shown in the Table 3, there are $13(13 \%)$ students with low and very low, and also there are $61(61 \%)$ students with high and very high academic success level. According to findings it can be said that students' academic success level is high in general.

\section{Relationship between Students' Democratic School Climate Scores and Sense of Community in the School Scores}

Information about whether there is a relationship between students' democratic school climate (DSC) scores and sense of community in the school (SOCIS) scores or not, is given in the following table.

Table 4. Relationship between DSC and SOCIS scores

\begin{tabular}{|c|c|c|c|}
\hline & & DSC & SOCIS \\
\hline \multirow{3}{*}{ DSC } & Pearson Correlation & \multirow{3}{*}{1} & \multirow{3}{*}{$\begin{array}{l}.30 * * \\
.001 \\
114\end{array}$} \\
\hline & Sig. (2-tailed) & & \\
\hline & $\mathrm{N}$ & & \\
\hline \multirow{3}{*}{ SOCIS } & Pearson Correlation & \multirow{3}{*}{$\begin{array}{l}.30 * * \\
.001 \\
114\end{array}$} & \multirow{3}{*}{1} \\
\hline & Sig. (2-tailed) & & \\
\hline & $\mathrm{N}$ & & \\
\hline
\end{tabular}

**Correlation is significant at the 0.01 level (2-tailed). 
According the table 4, there are medium- level, positive and significant relationship between students' perceptions about democratic school climate and their sense of community in the school $(\mathrm{r}=0.30, \mathrm{P}<.01)$. Accordingly, we can say that as the students' perception about democratic school climate increases, their sense of community in the school also increases.

\section{Result and Suggestions}

The results of this study have shown that teachers give importance to students' respectful behaviors to each other. There is a low relationship between academic success and democratic school environment and sense of community in the school. Students' perceptions about democratic school climate are medium level and above. While $40 \%$ of students who take part in the study have high sense of community level in the school, $32 \%$ of them have low. Although students' perceptions about democratic school climate which is medium and above seem fine, it does not mean that it is enough. Making arrangements that guarantee the democratic rights of students and allowing these arrangements to be used can help to make the school climate more democratic.. However, there must be collaboration, because school climate is more than individual experience: It is a group phenomenon that is larger than any one person's experience. A sustainable, positive school climate fosters youth development and learning necessary for a productive, contributive, and satisfying life in a democratic society. This climate includes norms, values, and expectations that support [1]. If the aim of educators is to promote a positive school climate, especially as perceived by students, it is important that they recognize that students value a combination of techniques, both positive and punitive, to manage their behavior and develop their social and emotional competencies [3].

Another important result of the study is that students do not have enough voice in how the school is run. While planning, practicing and evaluating the teaching process, students should be given more voice. Collective works, projects and social activities which develop students' sense of community in the school should be included. School environments must take as a goal not being oppressive, being a participant, raising individuals being able to do collaboration and team work, gaining a culture of argument

\footnotetext{
${ }^{\mathrm{i}}$ This study was presented at VI. International Conference on Critical Education (August 10-13, 2016, London, England).
}

and compromise, being able to distinguish between rights-freedoms and duties- responsibilities, obeying to rules and adhering to justice, being creative and inquisitive, asking and questioning. For such a training, not only the physical characteristics of the school but also all the other factors are necessary to establish a democratic environment based on human rights and freedoms. According to Gözütok [4] authoritarian school and class environments cannot raise democratic individuals who have embraced rights and freedoms. According to İnan [5], democratic education can be gained by the application of democratic principles in school and class. Mistakes decrease as long as you experience; traditions form and become habits as long as the time passes, so that the society can have settled values [6].

In other researches to be made in this regard, the following suggestions can be made: This study is conducted based on quantitative research design, so that qualitative studies can be done based on observations and interviews on this subject. This study was conducted on 114 students in a class. Similar studies can be done on a wider universe.

\section{REFERENCES}

[1] Cohen, J, Mccabe, EM, Michelli, NM, Pickeral, T. School climate: research, policy, practice, and teacher education. Teachers College Record. 2009; 111 (1), 180-213.

[2] Freiberg, HJ. (Ed.). School climate: measuring, improving and sustaining healthy learning environments. Philadelphia: Falmer Press; 1999.

[3] Bear, GG, Yang, C, Mantz, LS, Harris, AB. (2017). School-wide practices associated with school climate in elementary, middle, and high schools. Teaching and Teacher Education. 2017; 63 (2017), 372-383.

[4] Gözütok, D. Hukuk ilintili yurttaşlık eğitimi - hukuk öğretimi ve hukukçunun eğitimi uluslararası toplantı. Ankara: Türkiye Barolar Birliği Yayınları, 2003.

[5] İnan, MR. Demokrasi eğitiminde boyutlar ve sorunlar (panel I) - demokrasi için eğitim. Ankara: Türk Eğitim Derneği Yayınları, 1989, p.94-98.

[6] Kışlalı, AT. Demokrasi eğitiminde öneriler (panel II) demokrasi için eğitim. Ankara: Türk Eğitim Derneği Yayınları, 1989, p.137-143. 